\title{
Section XII: Surrender
}

\begin{abstract}
Rule 102
Enemy military personnel and civilians who have been directly participating in hostilities who manifest the intent to surrender and who comply with the additional requirements of Rules 103 and 104 are hors de combat and may not be denied quarter.
\end{abstract}

\section{Commentary}

1. "Manifest" means to express or demonstrate clearly.

2. The Rule applies to combatants and civilians participating directly in hostilities. The norm may also apply to other persons who are eligible for POW status. ${ }^{1}$ On persons eligible for POW status, see Rule 105.

3. Enemy personnel may offer to surrender themselves (and the military equipment under their control) to a Belligerent State. The obligation to accept valid offers to surrender is a LOAC rule that does not preclude a Belligerent State from prohibiting surrender by its own personnel within its own national jurisdiction. Domestic law, however, does not alter the LOAC obligation to accept such surrender, and the fact that a surrender was offered in violation of domestic law does not invalidate the surrender under international law.

4. The prohibition against denying quarter to those manifesting the intent to surrender is based on Article 23 (d) of the 1907 Hague Regulations ${ }^{2}$ and on

\footnotetext{
${ }^{1}$ GC/III, see chapter "Section I: Outer Space", fn. 19, Article 4.

${ }^{2} 1907$ Hague Regulations, see chapter "Section I: Outer Space", fn. 13, Article 23: "In addition to the prohibitions provided by special Conventions, it is especially forbidden: ... (d) to declare that no quarter will be given."
} 
Article 40 of AP/I. ${ }^{3}$ To deny quarter to an enemy means to refuse to accept an offer to surrender.

5. The requirement to accept surrender applies whether or not the person surrendering is able to fight.

6. Persons who resist in any way or otherwise continue to pose a threat to the enemy cannot be regarded as having surrendered.

7. It is unlawful to kill or injure persons who have surrendered regardless of whether or not they have combatant status.

8. If an individual soldier manifests the intent to surrender while his/her comrades continue to fight, difficult situations may arise. The following considerations should be borne in mind:

a. During an engagement, it may be impossible to distinguish between the individual who has attempted to offer his or her surrender and his/her comrades who continue the fight; and

b. The soldier purporting to surrender may be conspiring with his/her comrades, acting perfidiously in order to lure the enemy into a trap. See Rule 104 and the important conditions set out in Rule 103.

9. In a non-international armed conflict, any persons - including members of armed forces and of non-state armed groups-may give themselves up for capture and thereby receive the protection specified in Rule 106.

\section{Rule 103}

In order to be valid, surrender must meet the following conditions:

(a) The offer to surrender is communicated in a clear manner to the enemy.

\section{Commentary}

1. This Rule is based on Article 41(2) of AP/I and Article 23(c) of the 1907 Hague Regulations, which has customary law status.

2. If the forces of a Belligerent State are unaware of the intent to surrender, they cannot be expected to desist from further attacks.

3. If a person makes an attempt to communicate an intent to surrender in a manner that is not clear, the condition is not met. However, if circumstances permit, the enemy should make reasonable efforts to seek clarification.

4. Surrender must be distinguished from retreat. The mere fact that retreating personnel have disposed of their weapons, ought not to be confused with the concept of laying down of arms referred to in Common Article 3 of GC I-IV, which manifests an intent to surrender.

5. In land warfare, traditional ways of communicating intent to surrender are to lay down one's weapons and to raise one's arms. The display of a white flag, ${ }^{4}$

\footnotetext{
${ }^{3}$ AP/I, see chapter "Section I: Outer Space", fn. 13, Article 40: "It is prohibited to order that there shall be no survivors, to threaten an adversary therewith or to conduct hostilities on this basis."

${ }^{4} 1907$ Hague Regulations, see chapter "Section I: Outer Space”, fn. 13, Article 32.
} 
which once meant only a request to parley, is today also used as a means of communicating an intention to surrender.

6. In naval warfare, the traditional signal of surrender is to strike the flag.

7. Unlike land warfare, the practice of air warfare does not reveal any commonly accepted indication of an aircrew's wish to surrender. ${ }^{5}$

8. Rule 103 (a) applies mutatis mutandis to capture in non-international armed conflict (see paragraph 9 of the Commentary to Rule 102).

9. It must be borne in mind that in an international armed conflict waged between two or more adverse parties that do not share a common language, linguistic problems may arise in the communication of an intent to surrender. Every effort must be made to surmount such difficulties.

\section{(b) The offer to surrender is genuine.}

\section{Commentary}

1. For further discussion, see Commentary to Rule 104.

2. In air warfare, aircrews or aircraft operators - as with persons in land or naval warfare-must assess in good faith whether persons are offering a genuine surrender based on the information that is available to them at the time. There is no obligation to presume that a person is hors de combat if there is doubt as to the genuineness of a surrender.

3. The obligation to manifest the intention to surrender lies with the individual who offers to surrender. Thus, the offer to surrender must be communicated under circumstances where it can be properly received and understood by the enemy forces.

4. Whether an offer to surrender must be regarded as genuine relies on a balancing of several factors, including:

a. Time available for deliberation and for consideration of ambiguous offers of surrender.

b. Risk to the attacking party.

c. Cultural mores of the enemy forces with respect to surrender.

d. Prior history with respect to the conduct of the enemy forces in similar situations.

e. Enemy history of compliance with LOAC, including with respect to perfidy.

f. Other considerations that may bear on the genuineness of the offer.

5. If there is indeed a genuine offer to surrender and other requirements set out in the present Section are met, the surrendering person is protected from attack for as long as he or she remains in the power of the capturing party. For comments on the duty to release captured enemy combatants, see Rule 105(a).

\footnotetext{
${ }^{5}$ AMW Manual, see chapter "Section I: Outer Space”, fn. 1, Comment 2 on Rule 128.
} 
6. A previous reneging on an offer to surrender or the resumption of hostile acts subsequent to an offer to surrender can constitute prima facie evidence that the offer is not genuine.

7. Rule 103(b) applies mutatis mutandis to capture in non-international armed conflict.

\section{(c) The offer to surrender must be unconditional}

\section{Commentary}

1. This requirement is reflected in Article 23(c) of the 1907 Hague Regulations, which provides the surrender must be "at discretion".

2. The expression, "at discretion" implies that if the person offering to surrender poses certain conditions, and these conditions are accepted, then (and only then) the surrendering individual becomes hors de combat. ${ }^{6}$

\section{(d) Those offering to surrender have laid down their arms and do not engage in any further hostile acts.}

\section{Commentary}

1. This Rule is based on Article 41(2) of AP/I.

2. A person engaging in hostile acts cannot be regarded as having laid down his/her arms.

3. Hostile acts may include acts like transmitting intelligence to the enemy. Such acts are not compatible with surrender.

4. Killing or injuring an adversary while feigning surrender amounts to the war crime of perfidy. ${ }^{7}$ For States Parties to AP/I the same applies to capturing an enemy while feigning surrender.

5. Rule 103 (c) applies mutatis mutandis to capture in non-international armed conflict (see paragraph 9 of the Commentary to Rule 102).

(e) No attempt is made to evade capture.

\section{Commentary}

1. This Rule is based on Article 41(2) of AP/I.

2. A person who tries to evade capture has not laid down his/her arms in the legal sense, and is not hors de combat. He/she can therefore be attacked.

3. An individual on the ground or at sea who surrenders to an aircraft must stay visible to the aircraft and obey any instructions given until he/she can be taken into custody by any aircraft, vessel or ground forces called to the scene by the capturing aircraft. For situations where capture is under no circumstances feasible, see Rule 104.

\footnotetext{
${ }^{6}$ DoD Law of War Manual, see chapter "Section II: Cyber Operations", fn. 4, 5.9.2.3.

${ }^{7}$ AP/I, see chapter "Section I: Outer Space”, fn. 13, Article 37.
} 
4. Rule 103 (d) applies mutatis mutandis to capture in non-international armed conflict (see paragraph 9 of the Commentary to Rule 102).

(f) Those who offer to surrender strictly comply with instructions from the adversary.

\section{Commentary}

1. See paragraph 3 of the Commentary to Rule 103(e).

2. The obligation to comply strictly with instructions issued by the adversary also applies to ground forces wishing to surrender to an aircraft. See further the Commentary to Rule 104.

3. Rule 103 (e) applies mutatis mutandis to capture in non-international armed conflict (see paragraph 9 of the Commentary to Rule 102).

\section{Rule 104}

An offer to surrender may not be genuine if manifested in circumstances in which it is not feasible for the opposing party to accept the surrender. Accordingly, the offer of surrender by ground forces to an aircraft may be invalid if taking the forces into custody is not feasible in the prevailing circumstances.

\section{Commentary}

1. This issue was subject to lengthy discussions among the Group of Experts.

2. Two scenarios may illustrate the problem:

a. A military aircraft flying over enemy positions behind enemy lines discovers an enemy tank and observes that its crew has raised their hands. There are two issues here: (i) whether the conditions laid down in Article 103(a) through (e) appear to have been fulfilled and (ii) whether capture can be effected under Rule 104.

b. For example, if a small unit the size of a patrol operating in contested territory encounters an enemy infantry battalion offering to surrender, capture may not be possible. This example must, however, be understood without prejudice to Article 41(3) of AP/I and the duty to release combatants who have fallen into the power of the enemy under unusual circumstances that prevent their evacuation. ${ }^{8}$ See also Rule $105(a)$.

3. Surrender by ground forces to aircraft raises problems of factual impracticability in the taking of such persons into custody. Different views were expressed

\footnotetext{
${ }^{8}$ AP/I, see chapter "Section I: Outer Space", fn. 13, Article 41(3): "When persons entitled to protection as prisoners of war have fallen into the power of an adverse Party under unusual conditions of combat which prevent their evacuation as provided for in Part III, Section 1, of the Third Convention, they shall be released and all feasible precautions shall be taken to ensure their safety." The customary status of this rule is confirmed by several military manuals, including the $U S$ DoD Manual, see chapter "Section II: Cyber Operations", fn. 4, para 9.9.3.
} 
among the Group of Experts. According to some of the Experts, the possibility of the taking of such persons into custody is irrelevant to the genuineness of the offer to surrender. Another view would preclude ground forces from gaining hors de combat status vis-a-vis an aircraft because an offer to surrender cannot be genuine when it is factually impossible for the opposing party to accept. According to an intermediate view, the validity of the offer by forces surrendering to an aircraft has to be determined on a case-by- case basis (e.g., when there is an effective possibility of capture owing to the proximity to the contact zone).

4. The conditions laid down in Rule 103(a)-(e) require mutually understood communication between those surrendering and the capturing personnel. See, in particular, paragraph 3 of the Commentary to Rule 103(b).

5. The crews of military aircraft are duty bound to accept genuine offers of surrender, but an offer is genuine only if made in circumstances in which it is feasible for the adversary to accept it. In practice, much depends upon the time available for deliberation and the level of risk to the attacking party.

\section{Rule 105}

(a) Unless released, captured persons who are entitled to Prisoner of War status must be transported, as soon as it is practicable, to a Prisoner of War Camp.

\section{Commentary}

1. This Rule is based on Articles $19 \mathrm{ff}$ of GC/III which expresses customary LOAC.

2. Captured enemy personnel must be evacuated as soon as possible to camps situated far enough from the combat zone to be "out of danger". The notion of "out of danger" must be understood according to the circumstances. For example, the phrase has been understood to mean that the camp should be out of range of enemy artillery.

3. The duty to transport to a Prisoner of War Camp applies to all those entitled to POW status who are not released, repatriated or hospitalized prior to the time of internment. When circumstances do not permit the legally required evacuation due to "unusual conditions of combat", those who are Party to AP/I must release enemy personnel in accordance with Article 41(3) of AP/I. ${ }^{9}$

4. Captured personnel who are not entitled to POW status may be interned in a camp other than a Prisoner of War Camp. However, the fundamental guarantees enumerated in Article 75 of AP/I must be observed. See also Rule 106 with regard to non-international armed conflicts.

5. POWs who are accused and convicted of crimes in accordance with applicable domestic or international law (see chapter "Section XVII: International Criminal

\footnotetext{
${ }^{9}$ See fn. 170.
} 
Law") may, instead of being interned in a POW camp, serve sentences of punitive confinement under the same conditions as those applying to members of the armed forces of the Detaining Power.

(b) Captured enemy combatants may be detained temporarily in a forward transit, screening or detention facility, or a field hospital.

\section{Commentary}

1. Article 19 of GC/III allows for temporary internment in a danger zone owing to the prevailing circumstances.

\section{Rule 106 \\ In non-international armed conflicts, the legal status of Prisoner of War does not apply, but all captured persons must at all times be treated humanely in conformity with applicable international standards, regardless of whether the captured persons are subjected to criminal prosecution.}

\section{Commentary}

1. Common Article 3 of the GC I-IV provides minimum safeguards standards for persons who have been deprived of their liberty. Those guarantees are reflective of customary LOAC. See also Article 5 of AP/II.

2. As a minimum, all persons deprived of their liberty in a NIAC must be:

a. Treated humanely without any adverse distinction founded on race, colour, religion or faith, sex, birth or wealth, or any other similar criteria;

b. Protected against violence to life and person, torture, or cruel, humiliating and degrading treatment; and

c. Afforded the judicial guarantees recognized as indispensable by civilized peoples, if subject to criminal proceedings. In this regard, see chapter "Section XVII: International Criminal Law".

Open Access This chapter is licensed under the terms of the Creative Commons Attribution 4.0 International License (http://creativecommons.org/licenses/by/4.0/), which permits use, sharing, adaptation, distribution and reproduction in any medium or format, as long as you give appropriate credit to the original author(s) and the source, provide a link to the Creative Commons licence and indicate if changes were made.

The images or other third party material in this chapter are included in the chapter's Creative Commons licence, unless indicated otherwise in a credit line to the material. If material is not included in the chapter's Creative Commons licence and your intended use is not permitted by statutory regulation or exceeds the permitted use, you will need to obtain permission directly from the copyright holder.

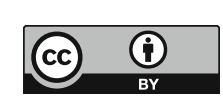

